\title{
Ashtabula Breakwater Common Tern (Sterna Hirundo) Nesting
}

\author{
By Thomas J. Fredette, Richard J. Ruby, Paul Bijhouwer, \\ Burton C. Suedel, Michael Guilfoyle, Marleen Kromer, \\ and Karen Adair
}

PURPOSE: This document summarizes the design features used to create a nesting area for the Common Tern (Sterna hirundo) that was incorporated as part of the maintenance repairs to the harbor breakwater located in Ashtabula, $\mathrm{OH}$. The purpose of the tern nesting project was to demonstrate an option that can be used during such maintenance activities for increasing infrastructure benefits as part of the Engineering With Nature initiative (Bridges 2012). The U.S. Environmental Protection Agency's Great Lakes Restoration Initiative (GLRI) and the U.S. Army Corps of Engineers' Dredging Operations and Environmental Research (DOER) Program sponsored the development of the nesting habitat site. The project was developed in consultation with the The Nature Conservancy and the Ohio Department of Natural Resources.

BACKGROUND AND PROBLEM: Engineering With Nature (EWN) is defined as the intentional alignment of natural and engineering processes to efficiently and sustainably deliver economic, environmental, and social benefits associated with water resources projects through collaborative efforts. EWN consists of four essential features. First, EWN uses science and engineering to produce operational efficiencies to support sustainable delivery of project benefits. Second, EWN uses natural processes to maximize benefits, thereby reducing demands on limited resources, minimizing the environmental footprint of projects, and enhancing the quality of project benefits. Third, EWN broadens and extends the base of benefits provided by projects to include substantiated economic, social, and environmental benefits. Fourth, EWN uses science-based collaborative processes to organize and focus interests, stakeholders, and partners to reduce social friction, resistance, and project delays while producing more broadly acceptable projects (Banks and Gerhardt-Smith 2013; Banks et al. 2013; Fischer et al. 2014).

One of the key needs for greater application of the EWN approach is a portfolio of demonstration projects. The Ashtabula Tern Nesting Habitat project was intended to serve that purpose as well as provide a secondary objective of reducing beneficial use impairments (i.e., impairments to any one of 14 beneficial uses such as restrictions on fish and wildlife consumption or dredging activities) within the Ashtabula Harbor designated Area of Concern (USEPA 2014).

Development of a human-made nesting habitat for the Common Tern and other tern species has been successfully accomplished both within the Great Lakes region (Karwowski et al. 1995, Riveredge Associates 2013) and in other regions (Floating Island International 2014). These earlier successes were an important factor in considering application of the approach for Ashtabula. They also provided valuable site selection and design experience on which the current project relied.

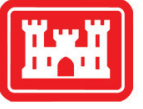

US Army Corps of Engineers ${ }_{\circledast}$
ENGINEERING WITH NATURE is the intentional alignment of natural and engineering processes to efficiently and sustainably deliver economic, environmental and social benefits through collaborative processes.

Approved for public release; distribution is unlimited.

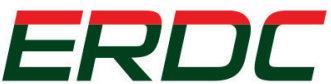

Engineer Research and Development Center 
The Common Tern (see photo on Page 1) is native to the Great Lakes, but it has become locally extinct in many regions, including Ashtabula, as a result of habitat loss and competition by more aggressive gull species. These impacts have directly contributed to the species being listed as an Ohio endangered species (Cuthbert et al. 2003). The closest known colonies to Ashtabula are about 120 miles to the east and west, but individuals are observed locally as migrants, thus the potential for reestablishing breeding colonies in the region with the creation of suitable habitat shows promise.

The GLRI funded the nesting habitat project in two phases, each of which involved installing about $250 \mathrm{ft}^{2}$ of nesting habitat integrated into a repair of the Ashtabula Harbor breakwater. Construction of the first phase was completed in 2013, and the second phase was installed in August 2014 once the nesting season was complete. This technical note describes the design used during Phase 1 . The completion of the second phase yielded a total nesting area of about $500 \mathrm{ft}^{2}$, which has the potential to support approximately 200 pairs of nesting terns (personal communication, Dave Sherman, Ohio Department of Natural Resources).

NESTING SITE DESIGN: Ashtabula Harbor, on the southern shore of Lake Erie, is protected by an attached 7,100 foot long breakwater at the western shore and by an unattached 4,400 foot long breakwater at the eastern shore (Figure 1).

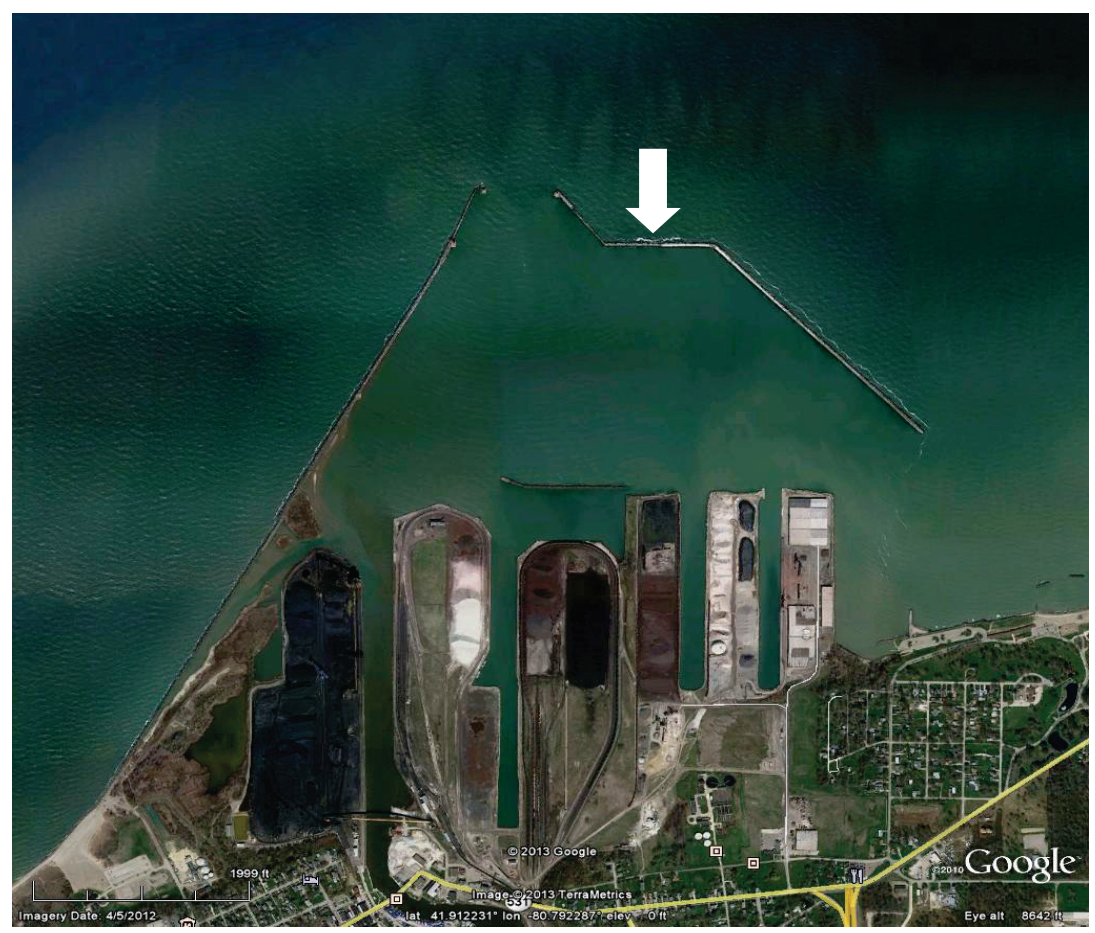

Figure 1. Aerial view of Ashtabula Harbor, $\mathrm{OH}$. The harbor is protected by a western breakwater attached to the southern shore of Lake Erie and an eastern breakwater that is not attached to land. The tern habitat was constructed on the middle leg of the eastern breakwater (arrow) (Map graphic, Google Inc.).

In 2013, the U.S. Army Corp of Engineers District in Buffalo, NY conducted annual maintenance on the unattached breakwater; likewise, they currently maintain these structures. 
Structure Land Connection Consideration. A structure that is not directly connected to land provides an important feature that may favor Common Tern site selection because it reduces the potential for predation on eggs and chicks by species such as minks and raccoons. Although minks are good swimmers and have become problems at other unattached breakwater nesting sites (Riveredge Associates 2012), the Ashtabula unattached breakwater helps to limit the concern for mammalian access as the closest point to land is over 1,000 feet away. Unattached structures also help to reduce potential human disturbance, since they are frequented far less often than attached structures.

Elevation Evaluation. As part of project planning for a Section 204 study, the Buffalo District conducted an analysis of the potential for storm-wave overtopping of the breakwater (USACE 2012). Section 204 of the Water Resources Development Act provides authority for the Corps to restore, protect, and create aquatic and wetland habitats in connection with construction or maintenance dredging of an authorized project. Based on this analysis, habitat blocks (see below) were installed at a higher elevation than the normal structure crest elevation to minimize the potential for wave destruction of nests or over-washing of young terns. This analysis used worstcase conditions, which are most likely to occur during the fall or winter, and thus there should be relatively low probability of wave disturbance during the nesting season.

Block Design. The repair material used at Ashtabula consisted of pre-cast concrete blocks. Large 8' x 8' x 4' blocks were used to form the base or toe of the structure, and smaller angled blocks were used to create the side slope with cap blocks at the crest (Figures $2 \& 3$ ). A Tern habitat was designed using modified toe blocks that were cast with a 6" deep recess in the top that could be filled with gravel suitable for a nesting habitat (Figure 3). Several drain holes, created by casting 3/4" ID PVC pipe into the blocks, were included so that water from rain and waves would not accumulate in the recesses. The recess was also set in from the edges of the blocks so that the lip would be unlikely to experience breaks during installation or as a result of environmental elements. In addition, in each corner of the recesses, a $23 / 8$ " ID, 1' long section of Schedule 40 PVC pipe was cast into the blocks. The PVC pipe was installed to create sleeves that could accommodate galvanized steel posts that were part of the avian competitor/predator exclusion measures that were also part of the habitat design (discussed below). A listing of materials and equipment used to construct the block nest habitat is shown in Table 1.

Structural Design. The nesting habitat feature consisted of a double row of stacked $8^{\prime}$ x $8^{\prime} \mathrm{x}$ 4' blocks. The first row was placed perpendicular to the breakwater crest, and the top row, the nesting blocks, were placed end-to-end, parallel to the breakwater alignment (Figure 2).

An alternative arrangement of placing the nesting blocks crosswise or side-by-side was considered and then eliminated from further consideration as this orientation was considered potentially less stable for the breakwater structure as a whole. From a habitat design perspective, it was believed that the side-by-side design might be better from a habitat suitability perspective, but because small nesting barges have been successful elsewhere, it is expected that the end-to-end design can attract terns to nest. In addition to placing the blocks on top of the wall, lengths of angle iron were bolted down to attach the nesting blocks to those below (Figure 4). Project engineers did not consider additional angle iron reinforcement of the first layer necessary, as they believed the frictional forces of the stacked blocks were sufficient for anchoring purposes. 
ERDC TN-EWN-16-1

May 2016

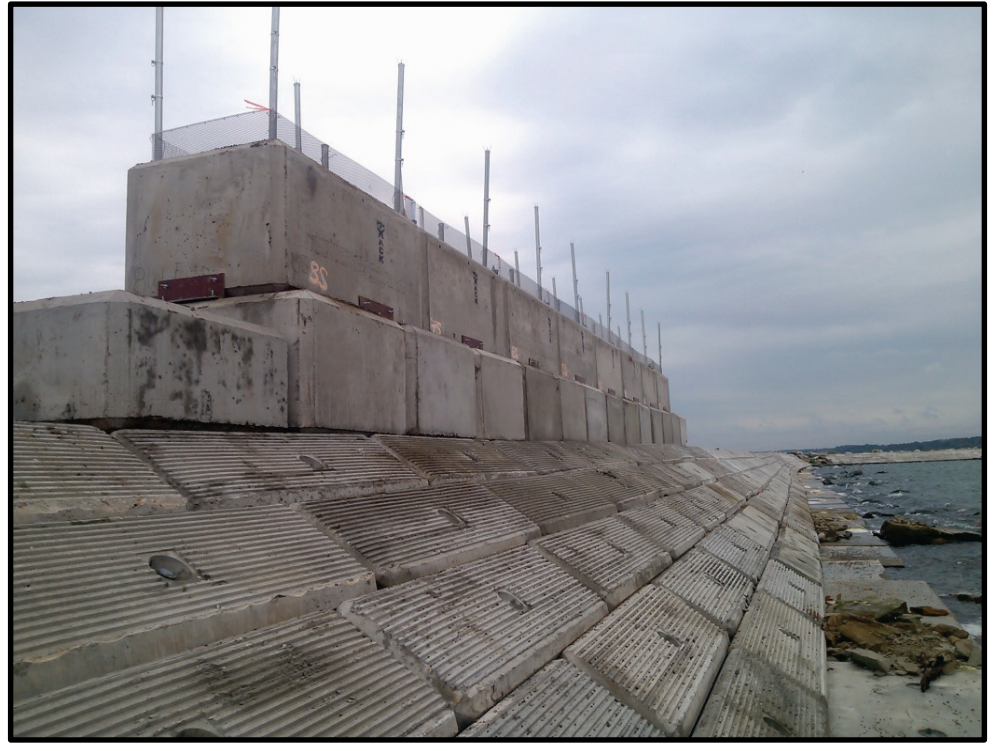

Figure 2. Nesting habitat blocks installed on the Ashtabula breakwater. Toe blocks are at the far right of the breakwater at water level.

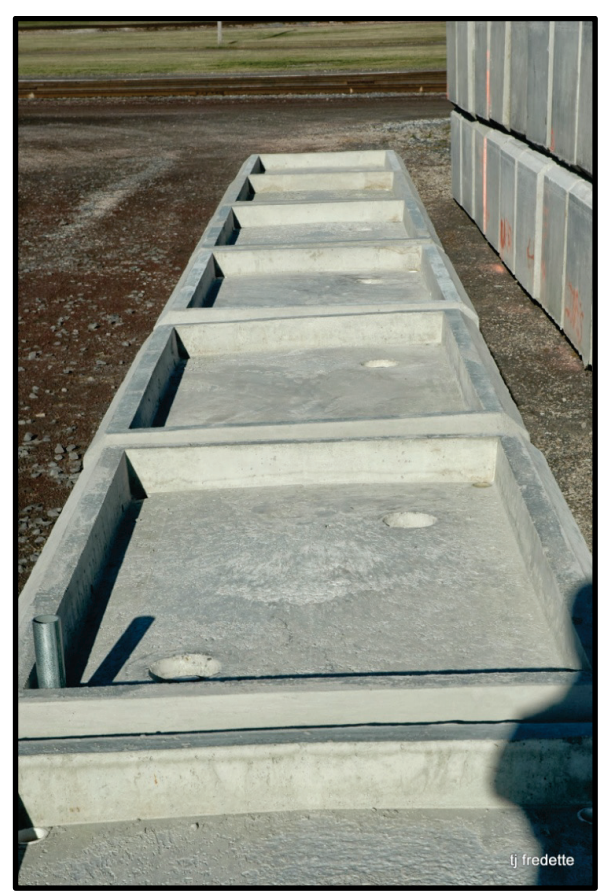

Figure 3. Modified toe blocks used for the tern habitat with top recess for nesting gravel. 


\section{Table 1. List of materials and equipment used for constructing habitat blocks in Phase 1.}

\begin{tabular}{|c|c|c|}
\hline Item & Number & Source \\
\hline $\begin{array}{l}\text { Habitat Block ( } 6 \text { " top recess, fence post } \\
\text { sleeves, drain holes installed) }\end{array}$ & 8 & Mack Industries, Brunswick, OH \\
\hline $\begin{array}{l}\text { SS } 40 \text { Galvanized Fence Posts ( } 23 / 8 " \\
\text { OD) }\end{array}$ & 22 & Allied Tube \& Conduit, Harvey, IL \\
\hline 2 3/8" Galvanized Fence Post Caps & 22 & Allied Tube \& Conduit, Harvey, IL \\
\hline $\begin{array}{l}23 / 8 \text { " Galvanized Chain-Link Fence } \\
\text { Brace Band }\end{array}$ & 36 & Local Hardware Supply \\
\hline $\begin{array}{l}\text { 1/2 “\#16 Expanded Stainless Steel Mesh } \\
4 \text { ' x 8' sheets }\end{array}$ & 6 & McNichols, Cleveland, OH 44128 \\
\hline Carabineers & 64 & Local Hardware Supply \\
\hline Nickel Plated Links & 110 & Local Hardware Supply \\
\hline 5/32" PVC Clothesline (100 ft/pkg) & 6 & Local Hardware Supply \\
\hline $\begin{array}{l}1 / 4 " \text { to } 1 / 2 " \text { Size Stone } \\
\text { \#9 Pea Gravel }\end{array}$ & $\begin{array}{l}5.5 \mathrm{yd}^{3} \\
\text { Delivered }\end{array}$ & $\begin{array}{l}\text { Simak Trucking and Excavating } \\
\text { N. Kingsville, } \mathrm{OH}\end{array}$ \\
\hline Wooden Decoys & $\begin{array}{l}6 \\
\& 6 \text { spare }\end{array}$ & $\begin{array}{l}\text { Mad River Decoy } \\
\text { Waitsfield, VT } 05673\end{array}$ \\
\hline Solar Powered Tern Call Box & 1 & $\begin{array}{l}\text { Murremaid Music Boxes } \\
\text { Bremen, ME } 04551\end{array}$ \\
\hline $\begin{array}{l}\text { Infrared, Motion Triggered Tiny W3 } \\
\text { Camera with Security Box, Batteries \& } \\
\text { Solar Connector Cable }\end{array}$ & 3 & GG Telecom, Victoriaville, QC, Canada \\
\hline $\begin{array}{l}\text { Salvaged/Scrap 5" x 24" x 3/4" boards } \\
\text { (non-treated) }\end{array}$ & & Local Salvage \\
\hline Driftwood & & Local Shorelines \\
\hline $\begin{array}{l}\text { Miscellaneous hardware (screws, wire, } \\
\text { nails) }\end{array}$ & & Local Hardware Supply \\
\hline
\end{tabular}




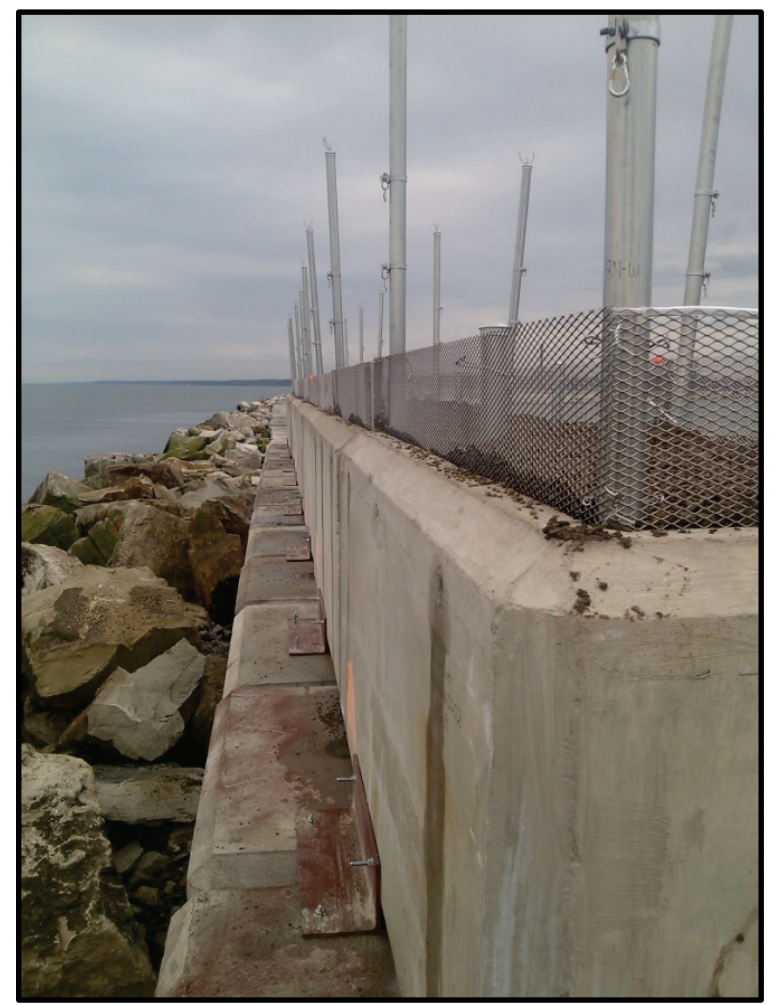

Figure 4. Angle iron cleats installed at the base of the habitat blocks to increase structural stability.

Materials and Construction Cost. Blocks were purchased for \$1,200 each, and two days of the LRB floating plant (barge with crane, tug, and crew) were needed to install the blocks. Other costs included the predator exclusion system, decoys, a solar powered tern call box, travel, and labor to install these items. Total costs of construction were approximately $\$ 55,000$ beyond the cost of the normal repair. Cost savings were realized as nest blocks were installed simultaneously with the placement of the repair blocks.

Nesting Area Design. The Phase 1 nesting site consisted of eight, 8-foot long blocks placed end-to-end for approximately $250 \mathrm{ft}^{2}$ of nesting area. The recesses in the blocks were filled with pea gravel of a size ( $1 / 4$ " to $1 / 2$ " size stone) utilized by Common Terns as nest sites (Figure 5). The nesting area was protected by a predator exclusion system, which consisted of side fencing, two sets of side cables, and an overhead grid of cables (Figure 6). The spacing in the overhead cables (about 1.5' x 2') was designed such that the relatively acrobatic and smaller Common Terns could access the site, but larger and less agile birds such as cormorants, gulls, and owls would be excluded. Gulls and owls are potential predators on eggs and chicks, and cormorants are a potential competitor for the space on the nest block habitat. The predator exclusion cables were attached to 6.5' long galvanized fence posts that were inserted into the PVC sleeves then cast into the concrete blocks. Posts were installed prior to filling the blocks with gravel. The cabling was cut and assembled while the blocks were set up shoreside prior to installation on the breakwater (Figure 6). Cables were attached to the posts using brackets, links, and carabineers (Figure 7). Longitudinal cable sections were made to reach the length of two blocks (16'), and the cross pieces 


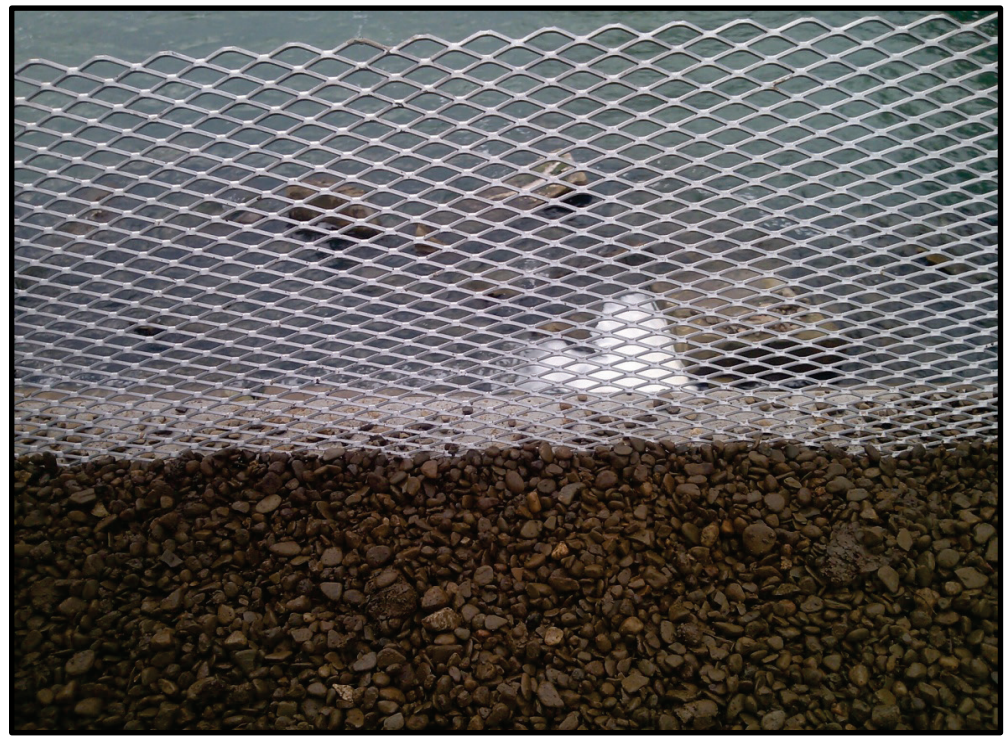

Figure 5. Pea gravel and stainless steel mesh fencing installed on the nesting habitat blocks.

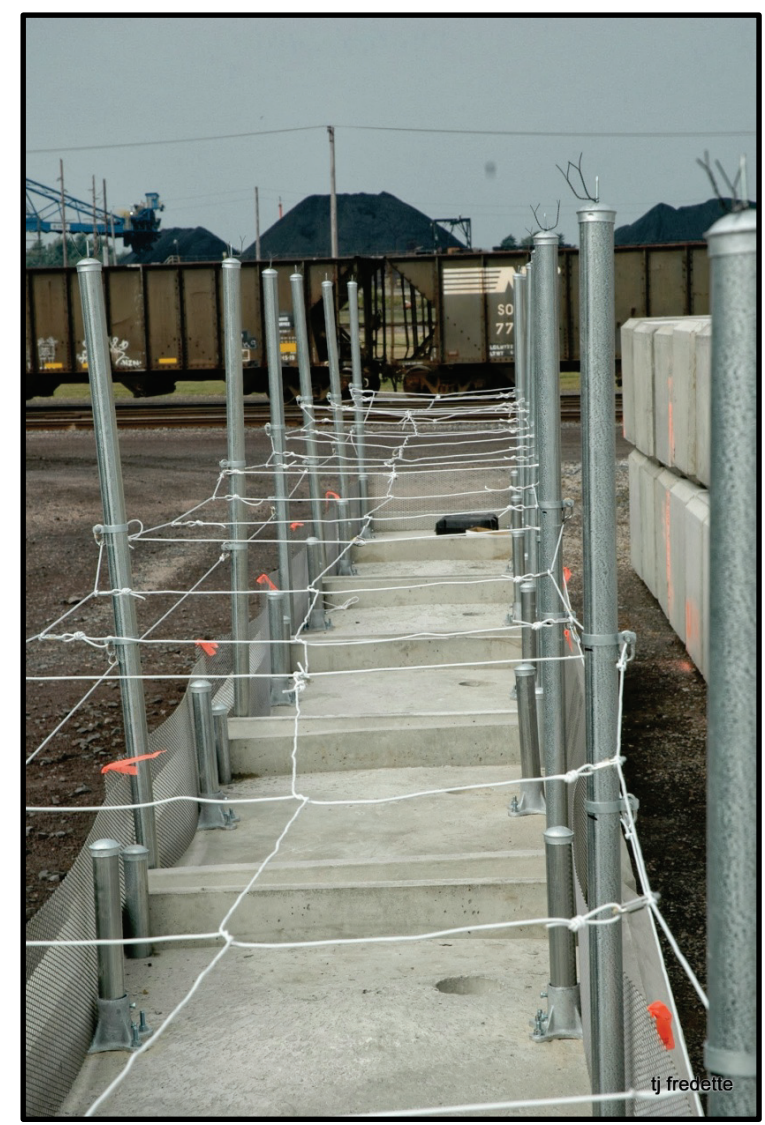

Figure 6. Predator/competitor exclusion cables. Cabling was measured, cut, and installed when the habitat blocks were still onshore. Once the installation was completed, the cable was removed for winter storage and subsequently reinstalled in spring. 


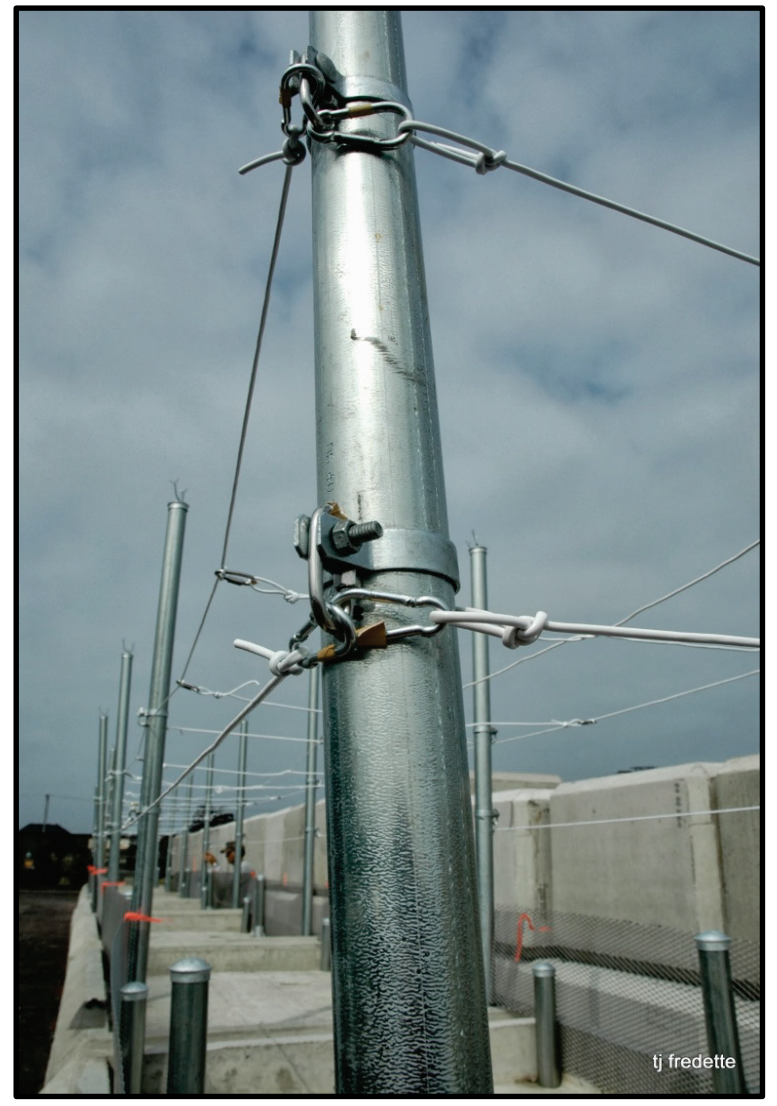

Figure 7. Carabineers and links used to attach the cabling for easy assembly and disassembly.

were all individual pieces. The cable was a coated 5/16" PVC clothesline. Posts were topped by a galvanized cap. The cap had a long screw installed with the tip pointing upward. The screw was attached to two pieces of twisted wire for deterring roosting by gulls (Figure 8). The side fencing was $1 / 2$ " expanded stainless steel mesh cut in 16" wide sections. In addition to keeping predators from accessing nests, the fencing was also intended to keep tern chicks from falling over the edge.

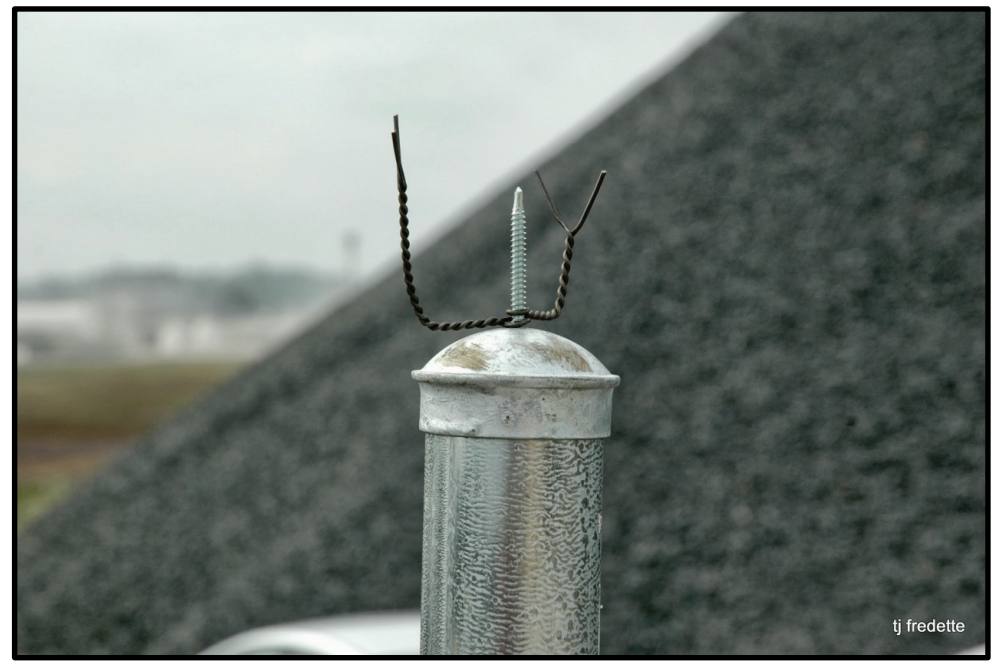

Figure 8. Gull roosting deterrent spikes on fence post caps. 
Tern decoys purchased from Mad River Decoy, Waitsfield, VT were made of hollow, rotomolded polyethylene material, filled with sand, and sealed with duct tape in order to keep strong winds from moving them. Six decoys were installed in two groups on the ends of the habitat area (Figure 9). The solar powered call box pictured in Figure 10 was purchased from Murremaid Music Boxes, Bremen, ME. Three infrared, motion sensitive SpyPoint cameras and power cables were purchased from GG Telecom, Victoriaville, QC, Canada and connected to the solar panel system to help document activities at the site. Volunteers coordinated by The Nature Conservancy made chick shelters using salvaged materials. Eight shelters were installed at the site in Phase 1. Driftwood was also randomly placed in the nest area to provide additional shelter and site complexity desired for nest site selection by terns (Figure 9).

SUMMARY: This document provides details on the construction of a demonstration project on the Ashtabula Harbor, $\mathrm{OH}$ breakwater intended to create a suitable nesting habitat for the stateendangered Common Tern. The first phase of construction was completed in 2013 in association with routine maintenance activities on the structure, and sought to intentionally broaden the benefits provided by the harbor protection project as part of the USACE Engineering With Nature Initiative. A second phase of construction was completed in the fall of 2014 and doubled the size of the nesting area.

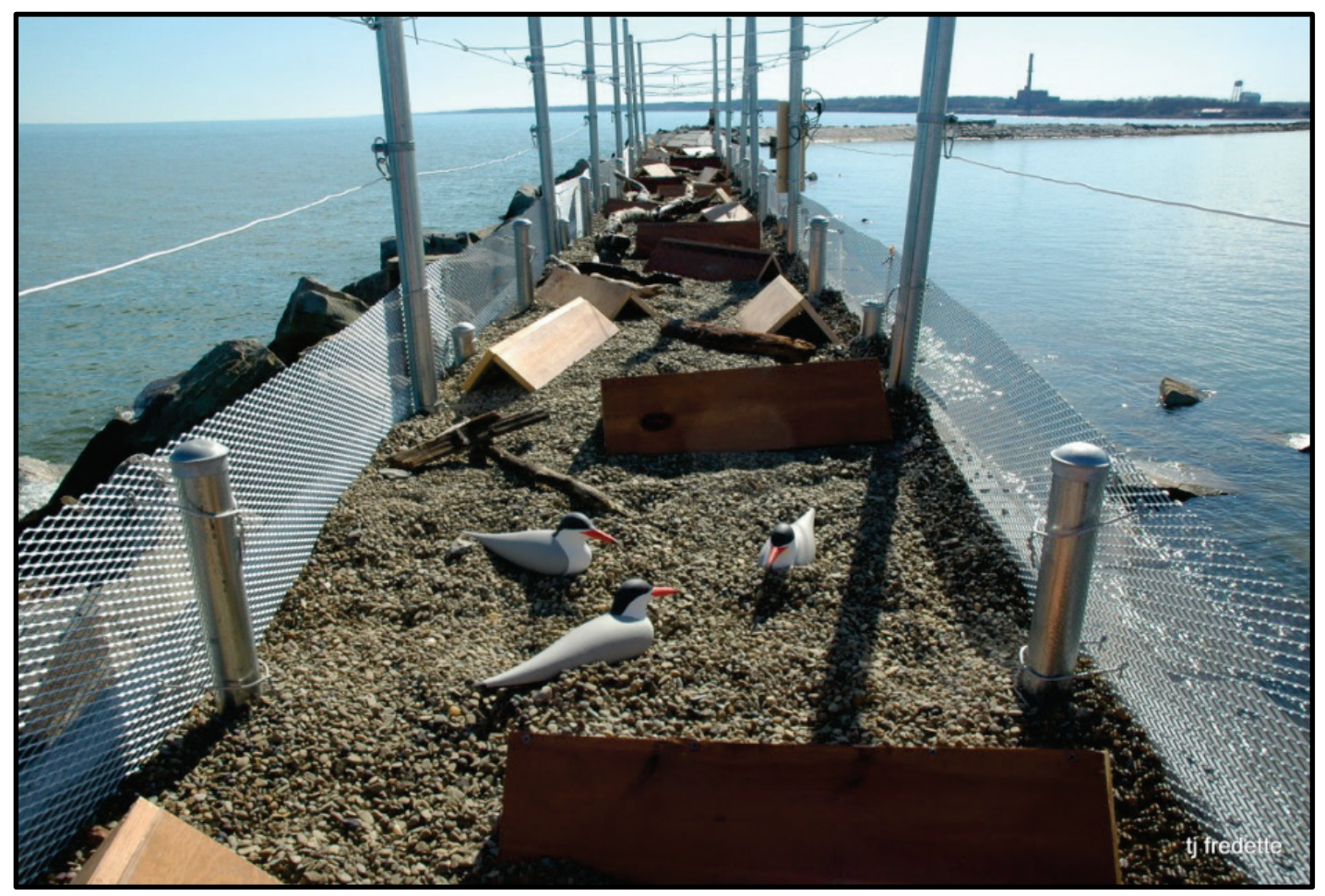

Figure 9. Tern decoys used to attract passing terns and chick shelters installed at the site. 


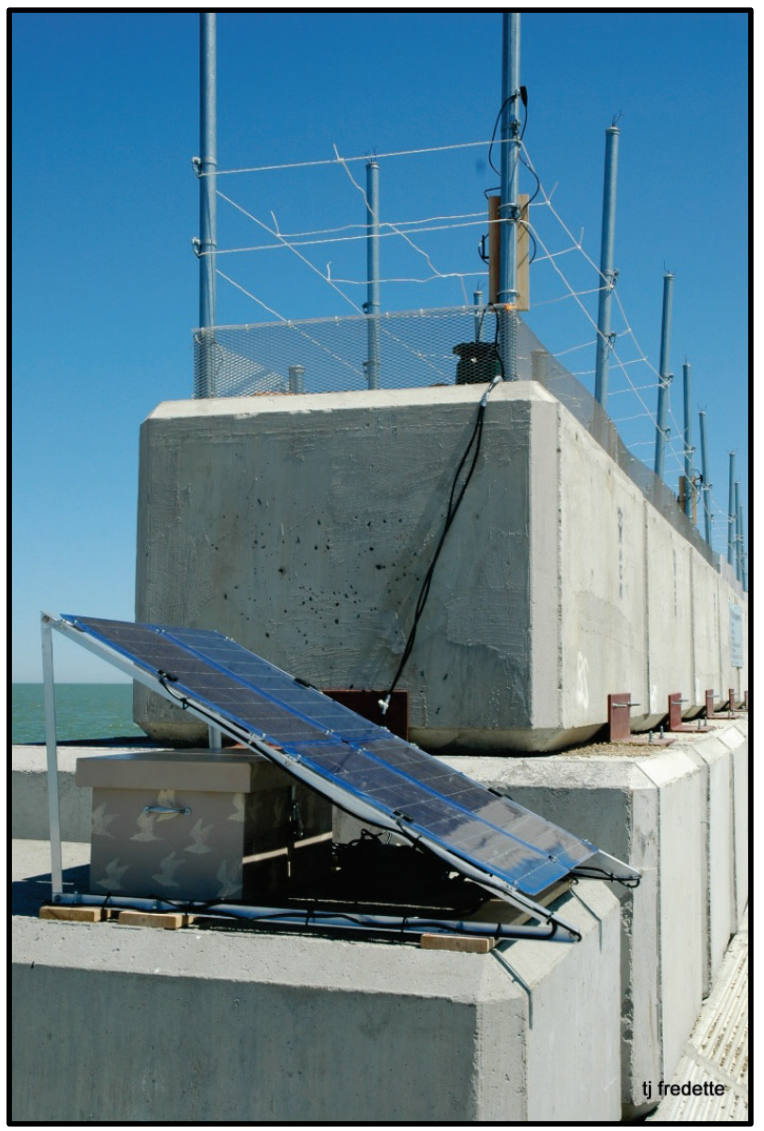

Figure 10. Solar powered tern-call system installed on the breakwater. Cables from the system power drum-shaped speakers located on each end of the habitat area.

Monitoring was conducted during the 2014 nesting season and will be continued through 2016, or longer, to assess the presence of adult terns and whether any nesting occurs. Terns did not colonize the site in 2014. If nesting does occur in 2015 or 2016, the number of nests, number of eggs, and nest success will be documented. The site will also be monitored for physical stability to determine whether the nesting blocks remain in place and maintain their physical integrity, if the predator exclusion system stays intact and is effective, and if the block recesses keep the gravel from getting washed out. Winter storms, waves, and ice build-up can combine to degrade the nest site integrity, and the monitoring results will be useful for informing design modification recommendations at this and other navigation structure sites where this habitat is installed.

POINTS OF CONTACT: For additional information, contact Dr. Burton Suedel (601-6344578, burton.suedel@usace.army.mil).This technical note should be cited as follows:

Fredette, TJ, RJ Ruby, P Bijhouwer, BC Suedel, M Guilfoyle, M Kromer, and K Adair. 2016. Ashtabula Breakwater Common Tern (Sterna hirundo) Nesting Habitat Site Design. EWN Technical Notes Collection ERDC TN-EWN-16-1. Vicksburg, MS: U.S. Army Engineer Research and Development Center. http://el.erdc.usace.army.mil/. 
ACKNOWLEDGMENTS: The authors thank Dave Sherman, Connie Adams, and Lee Harper for advice on site design. Sincere appreciation is also extended to Andrew Hannes, Captain Timothy Colburn, and the Floating Plant crew from the USACE Buffalo District for technical and logistical support.

\section{REFERENCES}

Banks, C. J., and J. M. Gerhardt Smith. 2013. Operationalizing Engineering With Nature - Regional Sediment Management Principles and Practices into Operations \& Maintenance Dredging Beneficial Use Project Management. ERDC TN-DOER-R20. Vicksburg, MS: U.S. Army Engineer Research and Development Center.

Banks, C.J., T.J. Fredette, B.C. Suedel, and T.S. Bridges. 2013. Implementing Engineering with Nature within the Corps: A Workshop. ERDC TN-DOER-R21. Vicksburg, MS: U.S. Army Engineer Research and Development Center.

Cuthbert, F.J., L.R. Wires, and K. Timmerman. 2003. Status Assessment and Conservation Recommendations for the Common Tern (Sterna hirundo) in the Great Lakes Region. U.S. Department of the Interior, Fish and Wildlife Service, Ft. Snelling, MN.

Recommendations for the Common Tern (Sterna hirundo) in the Great Lakes Region. U.S. Department of the Interior, Fish and Wildlife Service, Ft. Snelling, MN.

Fischer, R.A., Lott, C.A., and P. Hartfield. 2014. Conservation Actions Along Interior Rivers of the United States: Contributions to the Recovery of the Interior Population of Least Tern. WEDA Journal of Dredging14(2):1-15.

Floating Island International 2014. Floating Islands Enhance Salmonid Recovery by Creating Alternative Nesting Habitat for Caspian Terns. http://www.floatingislandinternational.com/wp-content/plugins/fii/casestudies/2.pdf (accessed 3 November 2014).

Karwowski, K., J.E. Gates, and L.H. Harper. 1995. Common terns nesting on navigational aids and natural islands in the St. Lawrence River, New York. The Wilson Bulletin 107(3): 423-436.

Riveredge Associates. 2012. Common Tern Habitat Improvement Project: 2011 Buffalo Harbor Tern Colony Enhancements and Status Assessment. Prepared for New York Power Authority. 29 pp.

Riveredge Associates. 2013. Common Tern Habitat Improvement Project: 2012 Buffalo Harbor Tern Colony Enhancements and Status Assessment. Prepared for New York Power Authority. 35 pp.

U.S. Army Corps of Engineers (USACE) 2012. Ashtabula Harbor - Section 204 Authority Ashtabula, Ohio. Appendix A: Coastal Engineering. US Army Corps of Engineers, Buffalo District. Buffalo, NY.

U.S. Environmental Protection Agency (USEPA) 2014. Great Lakes Areas of Concern. http://www.epa.gov/glnpo/aoc/ (accessed 8 January 2014). 